\title{
Anterior Tongue Carcinoma
}

National Cancer Institute

\section{Source}

National Cancer Institute. Anterior Tongue Carcinoma. NCI Thesaurus. Code C6249.

A carcinoma that arises from the anterior two-thirds of the tongue. Representative examples include squamous cell carcinoma, adenoid cystic carcinoma, and mucoepidermoid carcinoma. 